\title{
Architecture_MPS
}

\section{Assessing Sustainability in Housing LED Urban Regeneration: Insights from a Housing Association in Northern England}

Kevin Dean ${ }^{1, *}$, Claudia Trillo ${ }^{1}$

How to cite: Dean, K., Trillo, C. 'Assessing Sustainability in Housing LED Urban Regeneration: Insights from a Housing Association in Northern England'

Architecture_MPS, 2019, 15(1): 2, pp. 1-18. DOI:

https://doi.org/10.14324/111.444.amps.2019v15i2.001.

Published: 19 March 2019

\section{Peer Review:}

This article has been peer reviewed through the journal's standard Editorial double blind peer review.

\section{Copyright:}

(C) 2019, The Author(s). This is an Open Access article distributed under the terms of the Creative Commons Attribution License (CC-BY) 4.0 https://creativecommons.org/licenses/by/4.0/, which permits re-use, distribution and reproduction in any medium, provided the original author and source are credited • DOI: https://doi.org/10.14324/111.444.amps.2019v15i2.001

\section{Open Access:}

Architecture_MPS is a peer-reviewed open access journal. 


\title{
Title: Assessing Sustainability in Housing LED Urban Regeneration: Insights from a Housing Association in Northern England
}

\section{Authors: Kevin Dean, Claudia Trillo}

Architecture_media_politics_society. vol.15, no. 2.

March 2019

Affiliation: University of Salford, UK

\begin{abstract}
How far do current assessment methods allow the thorough evaluation of sustainable urban regeneration? Would it be useful, to approach the evaluation of the environmental and social impacts of housing regeneration schemes, by making both hidden pitfalls and potentials explicit, and budgeting costs and benefits in the stakeholders' perspective? The paper aims at answering these questions, by focusing on a case study located in the Manchester area, the City West Housing Trust, a nonprofit housing association. Drawing from extensive fieldwork and including several interviews with key experts from this housing association, the paper first attempts to monetize the environmental and social value of two extant projects - a high-rise housing estate and an environmentally-led program. It then discusses whether and how a stakeholder-oriented approach would allow more engagement of both current and potential funders in the projects at hand. Findings from both the literature and the empirical data that was gathered show how in current housing
\end{abstract}




\section{Amps}

regeneration processes, room for significant improvements in terms of assessment methods still exist. Findings additionally show that the environmental and social spillovers are largely disregarded because of a gap in the evaluation tools. This may also hinder the potential contributions of further funders in the achievements of higher impacts in terms of sustainability.

DOI: 10.14324/111.444.amps.2019v15i2.001, (C) 2019, The Authors. This is an Open Access article distributed under the terms of the Creative Commons Attribution License, which permits unrestricted use, distribution, and reproduction in any medium, provided the original author and source are credited. 


\title{
Title: Assessing Sustainability in Housing LED Urban Regeneration: Insights from a Housing Association in Northern England
}

\author{
Authors: Kevin Dean, Claudia Trillo
}

Architecture_media_politics_society. vol.15, no. 2.

March 2019

\section{Assessing Investment in Housing}

Following the economic crash of 2008, it became increasingly difficult for housing associations to comply with their mission. Due to the financial shortage, prioritizing investments in the right way is more important now than in the past. The current decision-making process on investment in housing is often undertaken without having a full understanding of all the related benefits, leading to an underestimation of the overall value of the investment itself. Part of the issue is related to the lack of a robust evaluation methodology, suitable to support with an evidence-based approach the financial assessment of all the positive effects. This paper aims at filling this gap, by exploring how far a more comprehensive assessment methodology, namely the Sustainable Return On Investment (henceforth: SuROI) approach, can be useful in uncovering those hidden benefits in the specific case of the social-housing sector. Efforts to demonstrate the usefulness of this methodology have been made in sectors other than social housing. Furthermore, the existing methodology has been developed up to the stage of providing stakeholders with a robust and evidence-based overall assessment of the value of the investment as a whole. This paper discusses the specific application of SuROI to the housing sector and suggests the potential applicability of SuROI in mapping benefits and costs across the stakeholders' community, allowing decision makers in the housing sector to negotiate the potential contributions of positively impacted beneficiaries. To do that, it first discusses the limitations of the most applied assessment methods and then introduces the basic principles of SuROI in order to pave the way for the calculation of the overall benefits of two case studies, both approached with two alternative methods, showing how SuROI 
allows the unveiling of benefits which are hidden in the traditional approach. The impact of this paper could be broad, since the issues highlighted above are related to a substantial and widespread problem that the findings go some way to addressing, as better clarified below.

Before the economic crash of 2008, housing associations relied heavily on bank financing to fund their development. Banks and other lenders historically provided housing associations with loans in favourable terms. Until the advent of the credit crunch, banks priced loans to housing associations at 20 to 30 basis points above the London interbank lending rate. ${ }^{1}$ However, once the credit crunch came about, not only did banks charge more for new loans, but they also sought to rewrite the already existing housing association loans they had outstanding. Housing associations seeking additional financing found that banks demanded rates as high as 300 basis points above LIBOR, often more than ten times higher than their previous rates. A number of lenders refused altogether to lend to housing associations. ${ }^{2}$ Banks sharply increased the cost of credit for housing associations, whilst demand for forsale homes and shared-ownership housing plummeted, reducing revenue for housing associations. ${ }^{3}$

Housing associations had increasingly been building housing for sale in the open market to generate additional revenue to help fund the development of social housing. The crisis left housing associations with thousands of unsold housing units, whilst additionally reducing the market value of the associations' housing stock and land holdings. Additionally, housing associations' ability to generate funds to support the development of social housing was curtailed, whilst the crisis also reduced the amount of housing acquired from private developers through the so-called Section 106 agreements, the legal agreements between local governments and developers that usually regulate the obligations of the latter with respect to the public burdens generated by the development process. A reduced revenue subsidy for social housing, notably via housing benefit, has contributed to the financial difficulties that housing associations currently face. In addition, a reduction of welfare support will impact on the ability of tenants to pay their rent, whilst the cutting of rent paid by tenants by 1 percent for at least the next couple of years has added to the challenges faced. To cap it all, the right-to-buy scheme can force associations to sell at huge discounts. Added to this, falling wages and a lack of employment add to the issues, whilst social housing is likely to be in even greater demand, ${ }^{4}$ putting even more pressure on housing associations.

\section{Critical Review of the Current Assessment Methodology}

Following the discussion of the current financial issues challenging housing associations, this section will set the context for understanding how the assessment of the urban regeneration strategies has been typically performed so far. The aim is to appreciate the innovation behind SuROI, in comparison to recent and/or current assessment methods commonly used to pre-assess the 
impacts of investments on housing in different programs or initiatives. The following methods, mainly related to governmental schemes, will be reviewed: (1) EGRUP Guidance, (2) City Challenge, (3) Single Regeneration Budget, (4) New Deal for Communities, (5) Urban Development Corporations, (6) Enterprise Zones, complemented by the following methods: (7) Hemphill framework, (8) Sustainable Urban Renewal Project Assessment Model, (9) INDicator-based Impact-assessment, (10) Regeneration Balance Sheet.

The interdepartmental Evaluation Group on Regional and Urban Programmes (EGRUP) uses a framework for the ex-post evaluation of expenditure and regeneration schemes. ${ }^{5}$ The framework measures value for money and cost effectiveness and emphasizes the need to clarify objectives, identifying the rationale for engaging in specific activities and assessing their value on markets. The guidance notes that all regeneration schemes ultimately have the same aim, to promote self sustaining environmental, economic and social regeneration in areas needing intervention. The guidance focuses on economic efficiency and covers the need for outlining the inputs, outputs and outcomes of an urban regeneration scheme. Shadow pricing techniques, statistical sources and proxies are used within the evaluation, but any stakeholder participation is not targeted to an actual scheme. It is consistently stated within the evaluation document that further research is required in the area of valuation for regeneration activities for which market-based information is not available.

City Challenge ${ }^{6}$ was commissioned by the DETR and aimed to regenerate thirty-one areas through Regeneration Partnerships which ran in deprived urban areas between 1991 and 1998 with the aim of improving specific rundown inner-city areas and the quality of life of local residents. ${ }^{7}$ City Challenge had an emphasis on partnerships, competitive bidding for resources, multiple objectives and a multi-sector approach to regeneration. ${ }^{8}$ Each City Challenge Partnership received $£ 37.5$ million over a five-year period, depending upon the satisfactory achievement of annually agreed targets and objectives. In terms of the evaluation of this scheme, there is no one method or framework in place to cover the multitude of partnerships. Indeed, the Final Evaluation of City Challenge ${ }^{9}$ found that there was an enormous diversity of local evaluations which translated to an insufficient level of consistency to make meaningful comparisons across all areas. A more standardized methodological approach was considered to have been of wider value. ${ }^{10}$ Additionally, the evaluations undertaken or commissioned by the partnerships themselves varied significantly in quality, content and approach, with some choosing to assess the effectiveness, efficiency and impact of a program, while others concentrated on updating baseline indicators. ${ }^{11}$ A key aspect of the schemes supported through the City Challenge Programme was their integrated nature - with traditional housing improvements being complemented by other regeneration projects concerned, for example, with job creation, training, and crime and community safety; however, no method was set up to capture any of this information in numerical and quantifiable format. The DETR ${ }^{12}$ touches on the 


\section{Amps}

notion of sustainable development, including a statement that if a regeneration program is to be regarded as successful, the outcomes it generates must be sustainable in some form; however, no method of measuring such aspects of sustainability is listed. Along the same lines, concern was also expressed within the City Challenge Final Evaluation on the lack of monitoring requirements for the quality of outputs or outcomes.

The Single Regeneration Budget $(\mathrm{SRB})^{13}$ was a single funding stream that resulted from the amalgamation of over twenty smaller regeneration-related programs. ${ }^{14}$ The aims of this program included bringing about multifaceted, economic and social regeneration in often relatively small neighborhood areas. ${ }^{15}$ The SRB evaluation methodology was designed to evaluate the process by which economic, social and physical regeneration is achieved at the local level. ${ }^{16} \mathrm{~A}$ cost benefit, inputs versus outputs approach was taken in the study. Additionally, outcomes were measured in terms of indicators in such areas as jobs created or safeguarded, enhanced pupil attainment, personal development of young people and community safety initiatives. ${ }^{17}$ There were three levels of outcomes involved within the evaluation. These levels cut across the distinction between social, economic and environmental goals and were termed delivery (the level of outputs), impact (the level of outcomes) and sustainability, termed as the longer-term social, economic and environmental impact over the life of a given partnership. Indicators were used to gauge economic benefits, housing benefits, social benefits, environmental benefits and community benefits, ${ }^{18}$ whilst an extensive baseline was also used. ${ }^{19}$ Social surveys and structured interviews were used to gauge opinions of key stakeholders within the SRB partnerships, together with an in-depth case study approach. ${ }^{20}$ The social surveys included resident surveys and business surveys. However, regarding the SRB evaluation, according to some researchers there was no attempt to make even a rough evaluation of the benefits ${ }^{21}$ and there were no clear conclusions as to how residents benefited from a given program. ${ }^{22}$ The methodology looks to cite overall net additional achievements; however, it is not able to quantify the holistic sustainable impact of the program in terms of all three aspects of the triple bottom line. In addition, it is stated that there are problems of comparability in the way the SRB is evaluated..$^{23}$

The New Deal for Communities (NDC) program, launched in 1998, was designed to help turn around the poorest of neighborhoods, ${ }^{24}$ thus reducing the gaps between some of the poorest neighborhoods and those of the rest of the country. ${ }^{25}$ The program's ten-year horizon reflected the concern that previous Area_Based Initiatives (ABIs) had not been given enough time to instigate change. Each NDC was expected to achieve positive change in relation to six outcomes. Three of the outcomes were intended to improve the thirty-nine places. These were crime, the local community, and housing and the physical environment. Three were to improve outcomes for people: education, health, and worklessness. ${ }^{26} \mathrm{~A}$ number of data collation and analysis tasks were central to the national evaluation, the most important of which was the biennial household survey. In 2002 a baseline was established across 
all thirty-nine NDC areas using a survey questionnaire. This addressed sociodemographic, status, and attitudinal considerations across all outcome areas. It was based on a random-sample survey design. Any change in NDC areas was benchmarked against other deprived, comparator areas. No previous evaluation of any English ABI at that time had been able to explore questions of net change across all relevant regeneration areas and their residents, for all outcomes, from a common baseline. ${ }^{27}$

Urban Development Corporations (UDCs) were created by the 1980 Local Government and Land Act and were brought about as a political and economic mechanism for unlocking the development potential of the inner cities. There appear to be a very small number of published evaluations of the performances of the $\mathrm{UDCs}^{28}$ whilst they also appeared to lack any form of systematic monitoring or evaluation. ${ }^{29} \mathrm{CLES}^{30}$ state that evaluations involved an incoherence of figures and that there was a lack of clear and consistent information within evaluations. According to Imrie and Thomas, ${ }^{31}$ evaluations are performance related with a limited range of criteria, such as "jobs created and safe-guarded, hectares reclaimed and quantities of constructed roadway." The emphasis in UDC evaluations is on value for money, with many commentators asserting that a greater range of non-quantifiable variables should have been accounted for within the scope of the evaluation. ${ }^{32}$

Enterprise Zones (EZs) were first introduced into the UK in the 1980s. Their objective was to create designated economic areas which were free of tax, regulation and constraints, and where dynamic businesses could grow. After first being introduced in the 1980s, EZs have since been reintroduced by the Coalition Government, in $2011 .{ }^{33}$ The final evaluation of the original EZs was carried out in $1995^{34}$ and assessed the extent to which EZs had generated both additional economic activity and physical regeneration. ${ }^{35}$ The evaluation methodology covered an analysis of data, which included annual monitoring data provided by the Department of the Environment, in combination with further data collected by consultants to quantify the additional economic activity generated. Main factors analyzed included employment characteristics, the number of firms established, industrial compositions of the firms within the zones, environmental improvements and impact on the local property markets. ${ }^{36}$ Additionally, the number of jobs and costs per job created were highlighted, but the evaluation made a limited assessment of any inward investment to the zones. ${ }^{37}$ Face-to-face and postal surveys were sent out to local companies to gauge their perceptions of EZ benefits. Lastly, studies were carried out to assess the effects of EZ policy on local property markets, the creation of new economic activity and impact on the physical environment.

Hemphill et al.'s framework ${ }^{38}$ measures sustainability by allocating a points score to indicators within five areas including economy and work, resource use, buildings and land use, transport and mobility and community benefits. Points are allocated to each indicator and to each indicator set. Indicators are used to measure the performance of regeneration against sustainability criteria. A points scoring framework is used. However, the authors add that 
"although it is possible to set indicator parameters for certain regeneration outputs (number of jobs created, amount of private-sector investment levered), it is difficult to extend the same rationale to more specific and intangible sustainability criteria (quality of life, community enterprise and the social economy)." 39 Additionally, although there are many sets of indicators or frameworks, there is no agreement on the application of this approach. ${ }^{40}$

The Sustainable Urban Renewal Project Assessment Model (SURPAM) is used as a planning tool for urban design professionals and aims to assess urban regeneration schemes from a sustainability point of view. ${ }^{41}$ It uses weighted indicators which are chosen by the author from prior research. The indicators resulted from survey and questionnaire research with prominent architects, planners and property development managers in Hong Kong, together with some local citizens. Subsequent factor analysis was carried out. All indicators fall under the triple bottom line. The model requires input from stakeholders and can be used to properly plan a prospective urban regeneration scheme. Through usage of the model, citizens are able to express opinion on the design of a particular proposal before it becomes a reality. Scores are expressed through multiplication of the weight of a design criterion by the score indicating the performance of a scheme with respect to an individual criterion.

The INDI (INDicator-based Impact-assessment) model was formed as a result of the $\mathrm{HQE}^{2} \mathrm{R}$ project developed under the leadership of French partners CSTB and La Calade. ${ }^{42}$ It is a communication and decision-support tool, which visualizes the results of impact assessment of different scenarios in a neighborhood. The sustainability potential of a particular neighborhood is measured on a "sustainability scale," with sustainability being defined by six principles (economic efficiency, social equity, environmental quality, long term, global, governance) and five global objectives: (1) To preserve and enhance heritage and conserve resources; (2) To improve the quality of the local environment; (3) To ensure diversity; (4) To improve integration; (5) To reinforce social life. The model works with sixty-three sustainable development indicators, which are linked to the five objectives above and their twenty-one more detailed targets. The tool consists of a spreadsheet, with the user inputting quantitative or qualitative values for the neighborhood for each indicator to get a resulting score. ${ }^{43}$

The remit of the Regeneration Balance Sheet ${ }^{44}$ is to ensure that evaluation maintains a focus on all aspects of the triple bottom line resulting from regeneration activity. The Regeneration Balance Sheet can be used either as a checklist, with ticks being placed in boxes to confirm that a particular piece of information is available to make an evaluation, or alternatively as an observation sheet regarding baseline information, objectives, indicators, outcomes or direction of change. The Balance Sheet is a very simple method of assessing sustainability impact within a regeneration scheme and can be classed as a tool for providing a structure to an evaluation and giving an overview of all its elements. ${ }^{45}$ Many authors note the usage of ad-hoc "check-lists" of sustainability without a clear methodological framework. ${ }^{46}$ 


\section{Towards a More Comprehensive Appraisal of the Impacts from Housing Investment: Implementing the Sustainable Return on Investment (SuROI) Approach}

The review of assessment methods and tools discussed in the previous section allows the assertion that, despite there being previous tools within the field of urban regeneration which have evaluated urban regeneration schemes, there appear to be none which take into consideration the hidden social and environmental benefits of a scheme. In addition, no tool then goes on to quantitatively measure such hidden benefits by the usage of "Sustainable Return on Investment" (SuROI). ${ }^{47}$ Sustainable Return on Investment is the method by which the assessment of hidden social and environmental benefits can be carried out. It incorporates such frameworks as Social Return on Investment (SROI) or Ecosystem Services Analysis (ESA). According to Nicholls et al., ${ }^{48}$ "things which get bought and sold take on greater significance." Sustainable Return on Investment takes this mantra on board ${ }^{49}$ and places a numerical value on the social and environmental components of the triple bottom line: aspects which are normally difficult to compare against more easily measured economic impacts. ${ }^{50}$ Other authors cite the typical difficulty in measuring the social "pillar" due to its abstract nature and consider that it could be overshadowed by the economic and environmental domains. ${ }^{51}$ Xing et al. ${ }^{52}$ cite that one of the main challenges can be a difficulty in the measurement of what they term "apples and pears," which is to compare the measurement of costs and values, which are expressed in different units. The SuROI method potentially solves this issue. In addition, recent guidance from the Royal Institution of Chartered Surveyors ${ }^{53}$ recognizes the need to include a wider range of factors that can influence the value of built environment projects and asserts that sustainability considerations are now considered as being important when undertaking valuations. ${ }^{54}$ The Social Value Act (2012) additionally requires that economic, environmental and social benefits are taken into consideration as part of any procurement processes, showing that the focus on sustainability is perhaps starting to change and become more important at national level also.

SuROI aims to allow the environmental and social value of a project, program or policy in the built environment to be made explicit through evidence and be added to capital costs to give an overall sustainable value. ${ }^{55}$ SROI compares the prospective social benefits of a particular scheme against its costs and ESA takes the costs and benefits of the environment into consideration. ESA covers both the natural and built environment, including architectural aspects within its definition. ${ }^{56}$

\section{Research Methodology}

To demonstrate how far SuROI can support a more comprehensive evaluation of the benefits deriving from investment in housing schemes, two extant case 


\section{Amps}

studies have been selected, drawing from a housing association based in northwest England. City West Housing Trust (CWHT) is a not-for-profit housing association, based in West Salford that owns and manages over 14,600 homes in the north-west of England. It launched in October 2008, following a stock transfer from Salford City Council. Almost $£ 250$ million has already been invested in homes and neighborhoods, and further major projects are underway. However, these projects work against a backdrop of difficult economic times. The two case studies to be covered within this paper have been chosen due to the range of housing types on offer, the amount of community engagement carried out with stakeholders by CWHT and the potential for future research. Both cases have been investigated by analyzing internal reports and documents and by interviewing selected key informants from CWHT.

The first case study is a high-rise scheme. CWHT has invested $£ 43.2 \mathrm{M}$ to improve 666 high-rise flats across nine blocks in Eccles, Salford. Improvements include approved thermal cladding, enclosed conservatory balconies, self-cleaning windows and new lifts, whilst internal improvements include remodelling to provide an open-plan living space as well as new kitchens, bathrooms, security doors and heating and ventilation systems. The figures below show before and after photos of the high-rise blocks.

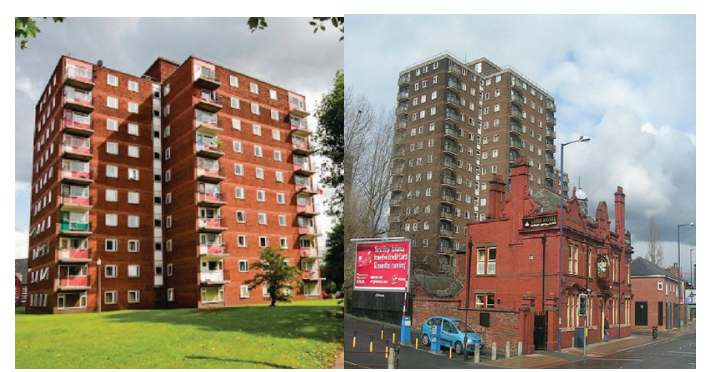

Figure 1: City West Housing Trust high-rise blocks before works. Source: author.

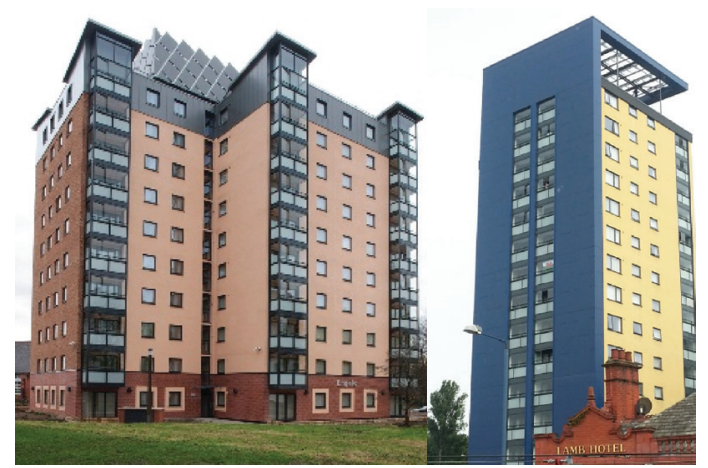

Figure 2: City West Housing Trust high-rise blocks after works. Source: author. 


\section{Amps}

The second case study is an environmental scheme. During 2014/15 CWHT delivered high specification environmental improvements to 476 customer homes. These improved the physical appearance of neighborhoods, enhanced property security and provided off-street parking. The figures below show photos of before and after the works.

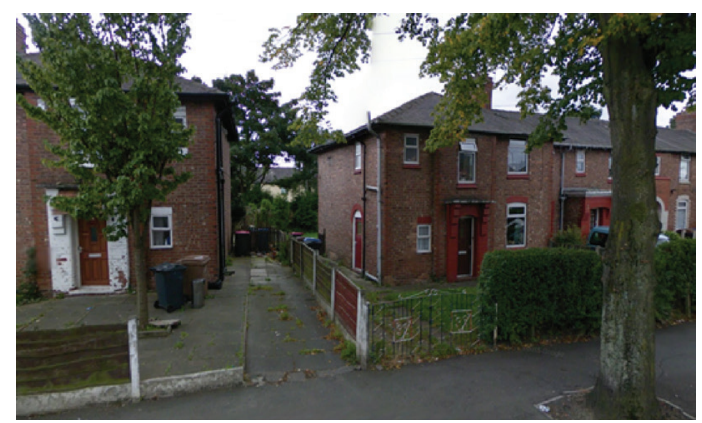

Figure 3: City West Housing Trust "environmental" scheme before works. Source: author.

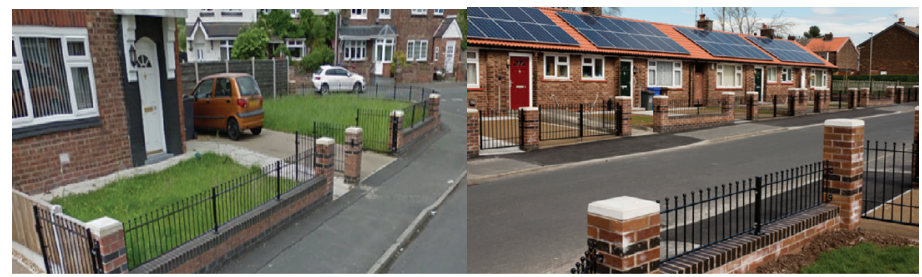

Figure 4: City West Housing Trust "environmental" scheme after works. Source: author.

\section{Case Studies Development}

The empirical evidence has been collected around the two case studies, as described in the previous section. In order to appreciate the contribution of SuROI to a better understanding of the benefits achievable through investment in housing, both case studies have been assessed twice, by adopting both a "traditional" approach and the SuROI approach, allowing a comparison of the numerical values from the two methods. As the "traditional" method, the authors decided to select the Single Regeneration Budget (SRB), ${ }^{57}$ because SBR Budget projects were subject to a considerable amount of monitoring and evaluation, and the review of the SRB conducted from the Department of Land Economy at Cambridge University ${ }^{58}$ had been referred to as the most extensive piece of evaluation work on the impact of urban regeneration interventions. Indeed, the SRB application spans quite a long period, running from 1994 until 2004 as part of a package of measures to make Government activity more responsible to local needs and priorities in England. There 


\section{Amps}

was also an encouragement of mainstream service deliverers to focus more resources on deprived areas. It was additionally more flexible than previous Government-led initiatives, in that it could vary according to size and geography. A hands-off management approach was also a common feature, with local partnerships being responsible for the management of their own regeneration schemes. ${ }^{59}$

There is a great deal of information available regarding the evaluation of the many SRB schemes carried out, including many reports, case studies and annexes. Rhodes et al. ${ }^{60}$ assert that one feature of a good evaluation framework is that it should enable the outputs or benefits of a policy or program to be compared with the inputs or costs, stating that it is only with information of this kind that an assessment of value for money can be made. Reference is also made to existing methodology being "too narrow, too heavily output based and full of estimation problems." It cites the issue of qualitative changes associated with regeneration outcomes, which can be given a quantitative dimension by "using sample survey techniques by indicating the extent to which perceptions in the resident population have changed." ${ }^{61}$ This is the exact technique used within our version of this study below.

However, in terms of a straightforward way of going about the evaluation process, the "suggested approach" provided by Rhodes et al. ${ }^{62}$ in paragraph A.1.2 of the full evaluation report's annexes will be used. This approach is as follows:

1) Obtain information on the activities and gross outputs associated with the SRB projects and the expenditure incurred disaggregated by key funding source;

2) Assess the additionality of SRB projects using five categories:

\begin{tabular}{lcc} 
& Range (\%) & Mid-point \\
\hline Negligible additionality & $0-9$ & 4.5 \\
Low additionality & $10-34$ & 22.0 \\
Medium additionality & $35-54$ & 44.5 \\
High additionality & $55-74$ & 64.5 \\
Very high additionality & $75-100$ & 87.5 \\
\hline
\end{tabular}

3) Other information will need to be assembled for the relevant projects relating to intended beneficiaries, displacement, substitution and leakage effects;

4) Assess the additionality of the public-sector financial contribution to the funding of the project. This will require an analysis of mainstream bending according to whether it has taken place over short or relatively long distances;

5) Establish the baseline position in relation to key outcome indicators in each SRB area drawing upon a range of published and unpublished data sources and through the use of social surveys; 
6) Establish evidence for each of the key outcome indicators in the SRB area at specific times during the life of the SRB and identify gross changes that lie behind the net outcomes. (The social surveys are essential in order to establish the gross changes that lie behind changes in net outcomes);

7) Combine evidence from project outputs with evidence on changes in area key outcomes, remembering that there are difficult measurement problems, that change takes place often only relatively slowly, and people move into and out of the areas that are the subject of the SRB assistance. This has clear implications for the scale of the survey work that should be undertaken.

The calculations undertaken on the high-rise scheme investment according to the SRB methodology and the SuROI approach show that by following the former methodology, the Net Present Value of impacts is $£ 2,853,144$ whilst by following the latter, SuROI approach, the total is $£ 24,101,336.08$. This implies a difference of $£ 21,248,192.08$, which represents the "invisible" benefit to society that SuROI allows the unveiling of, in comparison with the SRB. Likewise, the undertaking of similar calculations on the environmental-led scheme investment enables the unveiling of an extra Net Present Value of £2,183,060.79, stemming from the difference between the Net Present Value of the environmental scheme investment calculated following the application of SuROI, minus the Net Present Value of the same scheme calculated following the SRB methodology.

\section{Discussion and Conclusions}

Some observations can be gleaned from the comparison between the SRB evaluation and the SuROI approach. Within the SRB, there would appear to be a lot less information to hand from which to make strategic decisions or conclusions on the level of impact of a given scheme. In comparison, because the SuROI method in effect "makes the invisible visible," previously intangible areas become tangible, meaning that more information is readily available to decision makers, which in theory will increase the accuracy of decision making in the field of housing-led urban regeneration. Additionally, not all impacts of a scheme are going to be quantitative. The SRB-led methodology quantifies qualitative values in terms of the change in numbers of respondents or percentage change of response. This provides accurate information from directly involved stakeholders, but this perhaps does not bring into play sufficient supporting data. By utilizing the SuROI method, further indicator sets and proxies, brought about by tapping into sometimes thousands of responses again provide much more information, which in theory increases the accuracy of the impact and the accuracy of any subsequent strategic decision making.

It can be difficult via the traditional method of evaluation, to come to a conclusive decision on actually what the clear-cut, holistic and sustainable impact of the scheme is. There is no clear-cut, quantifiable and easy to understand 


\section{Amps}

ratio depiction of the impact or change promoted by a scheme, whereas within SuROI this is a fundamental part of the conclusion to the process. The traditional evaluation additionally struggles to adequately compare different forms of figures available. What is the value of one percentage point or one person's response within the evaluation? Is it the same or different from $£ 1$ of return? SuROI makes it easy to contrast figures and results, by quantifying them all in the common unit of a monetary value. Additionally, SuROI can use many different tools within its framework to gauge various impacts from social benefits to well-being, to environmental benefits. This makes SuROI a highly flexible and integrated approach. This level of flexibility and integration does not appear within the traditional evaluation. To ensure consistency in approach, SuROI's following of the Social Value SROI guidance principles brings about a discipline to an evaluation that does not appear to be present with the traditional evaluation approach involved with the SRB method. Lastly, with the SRB methodology, it would not be possible to predict the effects of a housing-led urban regeneration scheme which is planned for the future. With SuROI, because of the amount of data the method taps into, an accurate assessment could be gauged to again help strategic decision making.

In conclusion, in this paper we have highlighted that a gap exists in terms of evaluation methodology because current approaches do not highlight and make explicit previously intangible and hidden social and environmental impacts from housing-led urban regeneration schemes. The discussion and observations through the comparison of a traditional evaluation approach modeled on the Single Regeneration Budget program which ran from 1994 to 2004, with the evaluation method put forward as a viable alternative, that of Sustainable Return on Investment (SuROI), show that room for significant improvements in assessment methods still exists.

While environmental and social spillovers are largely disregarded because of a gap in the evaluation tools, implementing a more holistic and comprehensive methodology such as SuROI in the housing sector can be extremely beneficial in being able to capture those hidden benefits.

Finally, the assessment methodology can be easily adaptable by being refocused in terms of stakeholders' engagement. By repacking the financial calculation, allocating costs and benefits across the different stakeholders involved, it would be possible to attract potential new investors, willing to increase the benefits that the method has unveiled. A thorough exploitation exceeds the scope of this paper and will be discussed in depth in future development of this research.

\section{Notes}

1 House of Commons, Communities and Local Government Committee, Housing and the Credit Crunch. Third report of session 2008-09 (2009), accessed February 2, 2019, https://publications.parliament.uk/pa/cm200809/cmselect/ cmcomloc/101/10102.htm

2 M. Hilditch, "Spot the Difference," Inside Housing (2009); House of Commons. 
3 C. Dowler, "Shared Ownership Sales Slump," Inside Housing (Aug. 28, 2009).

4 D. Chevin, Social Hearted, Commercially Minded: A Report on Tomorrow's Housing Associations (2013).

5 HM Treasury, A Framework for the Evaluation of Regeneration Projects and Programmes (London: HMSO, 1995).

6 H. Russell, J. Dawson, P. Garside, and M. Parkinson, City Challenge: Interim National Evaluation (London: The Stationary Office, 1996).

7 DETR, Planning for Sustainable Development: Towards Better Practice (London: HMSO, 1998).

8 Department of the Environment, The SRB Evaluation Framework. Discussion Article 83 (Department of Land Economy, University of Cambridge, 1997).

9 DETR, Towards a Language of Sustainable Development (London: The Stationery Office, 2000).

10 DETR, Planning for Sustainable Development.

11 Ibidem.

12 Ibidem.

13 A. Brennan, J. Rhodes, and P. Tyler, Evaluation of the Single Regeneration Budget Challenge Fund (London: DETR, 1997).

14 D. Zuberi and A. Taylor, "Urban Renewal in Vancouver, Canada," in The Routledge Companion to Urban Regeneration, ed. M. E. Leary and J. McCarthy (London and New York: Routledge, 2013), 292-302.

15 J. Rhodes, P. Tyler, and A. Brennan, Evaluation of the Single Regeneration Budget: Final Evaluation (Cambridge: Department of Land Economy, University of Cambridge, 2007).

16 Department of the Environment, The SRB Evaluation Framework.

17 Zuberi and Taylor, "Urban Renewal."

18 Brennan et al., Evaluation of the Single Regeneration Budget Challenge Fund.

19 Rhodes et al., Evaluation of the Single Regeneration Budget: Final Evaluation.

20 Ibidem.

21 Ibidem.

22 S. Y. Ho, "Evaluating Urban Regeneration Programmes in Britain." Evaluation 5(4) (1999): 422-38.

23 DoE, The SRB Evaluation Framework. Discussion Article 83 (Cambridge: University of Cambridge: Department of Land Economy, 1997).

24 DETR, Planning for Sustainable Development.

25 DETR, New Deal for Communities Finance Guidance (London: DETR, 2001).

26 P. Lawless, "Understanding the Scale and Nature of Outcome Change in AreaRegeneration Programmes: Evidence from the New Deal for Communities Programme in England." Environment and Planning C: Government and Policy, 29(3) (2011): 520-32.

27 Ibidem.

28 R. Imrie and H. Thomas, British Urban Policy: An Evaluation of the Urban Development Corporations, 2nd ed. (London: Sage, 1999).

29 National Audit Office (NAO), The Achievements of the Second and Third Generation: Urban Development Corporations (London: HMSO, 1993). 


\section{Amps}

30 Centre for Local Economic Strategies (CLES), Inner City Regeneration: A Local Authority Perspective (Manchester: CLES, 1990).

31 Imrie and Thomas, British Urban Policy.

32 R. Hambleton and H. Thomas, eds, Urban Policy Evaluation: Challenge and Change (London: Paul Chapman Publishing, 1995).

33 G. Osborne, The Government Announces 11 New Enterprise Zones to Accelerate Local Growth as Part of the Plan for Growth (Press release, 2011).

34 HM Treasury, A Framework for the Evaluation of Regeneration Projects and Programmes (London: HMSO, 1995).

35 J. Potter and B. Moore, "UK Enterprise Zones and the Attraction of Inward Investment," Urban Studies 37(8) (2000): 1279-312.

36 HM Treasury, Framework for the Evaluation of Regeneration Projects.

37 Potter and Moore, "UK Enterprise Zones."

38 L. Hemphill, J. Berry, and S. McGreal, "An Indicator-Based Approach to Measuring Sustainable Urban Regeneration Performance: Part 1, Conceptual Foundations and Methodological Framework," Urban Studies 41(4), (2004): 725-55. "Part 2, Empirical Evaluation and Case-Study Analysis," Urban Studies 41(4) (2004): 757-72.

39 Ibidem, p. 726.

40 M. K. Ng, "Reference Tools," Social Indicators Research, 71(1-3) (2005): 441-65.

41 K. L. G. Lee, "Sustainable Urban Model for a High Density City - Hong Kong." Unpublished PhD Thesis. The Hong Kong Polytechnic University, 2008.

42 C. Charlot-Valdieu and P. Outrequin, ISDIS System and INDI Model: Assessment of Neighbourhood Regeneration Scenarios with a Sustainable Development Indicators System - Methodological Presentation, $H Q E^{2} R$. (Sophia Antipolis: CST-La Calade, 2004).

43 A. Blum and M. Grant, "Sustainable Neighbourhoods: Assessment Tools for Renovation and Development," Journal of International Research Publications: Ecology and Safety 1 (2006): 37-54.

44 C. Robbins, "The Regeneration Balance Sheet for Communities" (presentation at $\mathrm{HQE}^{2} \mathrm{R}$ work meeting No. 3 and working paper, Bristol, 2002).

45 Blum and Grant, "Sustainable Neighbourhoods."

46 H. Barton, ed.. Sustainable Communities: The Potential for Eco-Neighborhoods (London: Routledge, 2000); H. Barton, M. Grant, and R. Guise, Shaping Neighbourhoods: A Guide for Health, Sustainability and Vitality (London: Spon Press, 2013); S. Bell and S. Morse, Measuring Sustainability. Learning from Doing (London: Earthscan, 2003); D. A. Brownhill, Sustainability Checklist for Developments (Watford: British Research Establishment, 2002).

47 E. Bichard, "Developing an Approach to Sustainable Return on Investment in the UK, Brazil and the USA: A Report for the Royal Institution of Chartered Surveyors Research Trust," 2015.

48 J. Nicholls, E. Lawlor, E. Neizert and T. A. Goodspeed, A Guide to Social Return on Investment (Liverpool: SROI Network, 2012), 8.

49 Bichard, "Sustainable Return on Investment." 
50 S. Conejos, C. Langston, and J. Smith, J. "AdaptSTAR Model: A Climate-Friendly Strategy to Promote Built Environment Sustainability," Habitat International 37 (2013): 95-103.

51 M. Lehtonen, "The Environmental-Socio Interface of Sustainable Development: Capabilities, Social Capital, Institutions," Ecological Economics 49 (2004): 199-214; M. Davidson, "Social Sustainability: A Potential for Politics?" Local Environment 14 (2009): 607-19; B. Littig and E. Griessler, Social Sustainability: A Catchword Between Political Pragmatism and Social Theory," International Journal for Sustainable Development 8 (2005): 65-79.

52 Y. Xing, R. Horner, M. El-Haram, J. Bebbington, "A Framework Model for Assessing Sustainability Impacts of Urban Development," Accounting Forum 33 (2009): 209-24, p. 210.

53 RICS. RICS Valuation-Professional Standards (London: Royal Institution of Chartered Surveyors, 2014).

54 Bichard, "Sustainable Return on Investment."

55 Bichard, "Sustainable Return on Investment."

56 Department for Environment, Food and Rural Affairs. An Introductory Guide to Valuing Ecosystem Services (London: DEFRA, 2007).

57 F. Robinson, T. Blackman, and C. Stephens, Monitoring and Evaluating City Challenge, Research for Policy 1995 (Newcastle, UK: Local Authorities Research and Intelligence Association, 1995), 135-45.

58 J. Rhodes, P. Tyler, A. Brennan, S. Stevens, C. Warnock, and M. Otero-Garcia, Lessons and Evaluation Evidence from Ten Single Regeneration Budget Case Studies - Mid Term Report (London: DETR, 2002).

59 Ibidem.

60 Ibidem.

61 Rhodes et al. "New Developments in Area Based Initiatives in England: The Experience of the Single Regeneration Budget," Urban Studies 40(8) (2003): $1399-426$.

62 Ibidem.

\section{Bibliography}

Barton, H. ed. Sustainable Communities: The Potential for Eco-Neighborhoods. London: Routledge, 2000.

Barton, H., M. Grant, and R. Guise. Shaping Neighbourhoods. A Guide for Health, Sustainability and Vitality. London: Spon Press, 2013.

Bell, S., and S. Morse. Measuring Sustainability. Learning from Doing. London: Earthscan, 2003.

Bichard, E. Developing an Approach to Sustainable Return on Investment in the UK, Brazil and the USA. A report for the Royal Institution of Chartered Surveyors Research Trust, 2015.

Blum, A. and M. Grant. "Sustainable Neighbourhoods: Assessment Tools for Renovation and Development." Journal of International Research Publications: Ecology and Safety 1 (2006): 37-54. 


\section{Amps}

Brennan, A., J. Rhodes, and P. Tyler. Evaluation of the Single Regeneration Budget Challenge Fund. DETR: London, 1997.

Brennan, A., J. Rhodes, and P. Tyler. "The Distribution of SRB Challenge Fund Expenditure in Relation to Local-Area Need in England." Urban Studies, 36(2) (1999): 2069-84.

Brownhill, D. A Sustainability Checklist for Developments. Watford: British Research Establishment, 2002.

Centre for Local Economic Strategies (CLES). Inner City Regeneration: A Local Authority Perspective. Manchester: CLES, 1990.

Charlot-Valdieu C., and P. Outrequin. ISDIS System and INDI Model: Assessment of Neighbourhood Regeneration Scenarios with a Sustainable Development Indicators System - Methodological Presentation, $\mathrm{HQE}^{2} \mathrm{R}$ Deliverable. Sophia Antipolis: CSTLa Calade, 2004.

Chevin, D. Social Hearted, Commercially Minded: A Report on Tomorrow's Housing Association, 2013. Available at http://www.d4multimedia.com/genesis/Socialhearted.pdf. Accessed March 1, 2017.

Conejos, S. C. Langston, and J. Smith. "AdaptSTAR Model: A Climate-Friendly Strategy to Promote Built Environment Sustainability." Habitat International 37 (2013): 95-103.

Davidson, M. Social Sustainability: "A Potential for Politics?" Local Environment 14 (2009): 607-19.

Department of the Environment. The SRB Evaluation Framework. Discussion Article 83. Department of Land Economy, University of Cambridge, 1997.

Department for Environment, Food and Rural Affairs. An Introductory Guide to Valuing Ecosystem Services. London: DEFRA 2007.

Department of the Environment, Transport and the Regions. Towards a Language of Sustainable Development. London: The Stationery Office, 2000.

Department of Land Economy. Evaluation of the Single Regeneration Budget Challenge Fund: Annexes. University of Cambridge, 2002.

DETR. Planning for Sustainable Development: Towards Better Practice. London: HMSO, 1998.

DETR. New Deal for Communities Finance Guidance. London: DETR, 2001.

Dowler, C. "Shared Ownership Sales Slump." Inside Housing, Aug. 28, 2009. Available at http://www.insidehousing. co.uk/shared-ownership-sales-slump/6506100.article. Accessed March 1, 2017.

Hambleton, R. and H. Thomas. (eds) Urban Policy Evaluation: Challenge and Change. London: Paul Chapman Publishing, 1995.

Hemphill, L., J. Berry, and S. McGreal. "An Indicator-Based Approach to Measuring Sustainable Urban Regeneration Performance: Part 1, Conceptual Foundations and Methodological Framework." Urban Studies 41(4) (2004): 725-55. "Part 2, Empirical Evaluation and Case-Study Analysis." Urban Studies 41(4) (2004): 757-72.

Hilditch, M. Spot the Difference. Inside Housing, 2009. Available at http://www. insidehousing.co.uk/home/blogs/spot-the-difference/7006573.article. Accessed March $1,2017$. 


\section{Amps}

HM Treasury. A Framework for the Evaluation of Regeneration Projects and Programmes. London: HMSO, 1995.

HM Treasury. A Further Assessment of the Enterprise Zone Policy. London: HMSO, 1995.

Ho, S.Y. "Evaluating Urban Regeneration Programmes in Britain." Evaluation 5(4) (1999): 422-38.

House of Commons. Communities and Local Government Committee. Housing and the Credit Crunch. Third report of session 2008-09 (2009). Available at http://www. publications.parliament.uk/pa/cm200809/cmselect/cmcomloc/101/101.pdf. Accessed March 1, 2017.

Imrie, R., and H. Thomas. British Urban Policy: An Evaluation of the Urban Development Corporations, 2nd ed. London: Sage, 1999.

Lawless, P. "Understanding the Scale and Nature of Outcome Change in AreaRegeneration Programmes: Evidence from The New Deal For Communities Programme in England. Environment and Planning C." Government and Policy 29(3) (2011): 520-32.

Lee, K.L.G. "Sustainable Urban Model for a High Density City - Hong Kong." Unpublished PhD Thesis. Hong Kong: The Hong Kong Polytechnic University, 2008.

Lehtonen, M. "The Environmental-Socio Interface of Sustainable Development: Capabilities, Social Capital, Institutions.” Ecological Economics 49 (2004): 199-214.

Littig, B., and E. Griessler. "Social Sustainability: A Catchword Between Political Pragmatism and Social Theory." International Journal for Sustainable Development 8 (2005): 65-79.

NAO. The Achievements of the Second and Third Generation: Urban Development Corporations. London: HMSO, 1993.

Ng, M. K. "Reference Tools." Social Indicators Research 71(1-3) (2005): 441-65.

Nicholls, J., E. Lawlor, E. Neizert, and T. Goodspeed. A Guide to Social Return on Investment SROI Network. London and Liverpool: SROI, 2012.

Osborne, G. The Government Announces 11 New Enterprise Zones to Accelerate Local Growth as Part of the Plan for Growth (Press Release) 2011. Available at https://www. gov.uk/government/news/the-government-announces-11-new-enterprise-zones-toaccelerate-local-growth-as-part-of-the-plan-for-growth-2. Accessed March 1, 2017.

Potter J., and B. Moore. "UK Enterprise Zones and the Attraction of Inward Investment." Urban Studies 37(8) (2000): 1279-312.

Rhodes, J., P. Tyler, A. Brennan, S. Stevens, C. Warnock, and M. Otero-Garcia. Lessons and Evaluation Evidence from Ten Single Regeneration Budget Case Studies - Mid Term Report. London: DETR, 2002.

Rhodes, J., P. Tyler, A. Brennan, S. Stevens, C. Warnock, and M. Otero-Garcia. "New Developments in Area Based Initiatives in England: The Experience of the Single Regeneration Budget." Urban Studies 40(8) (2003): 1399-426.

Rhodes, J., P. Tyler, and A. Brennan. Evaluation of the Single Regeneration Budget: Final Evaluation. Cambridge: Department of Land Economy, University of Cambridge, 2007.

RICS. RICS Valuation - Professional Standards. London: Royal Institution of Chartered Surveyors, 2014. 


\section{Amps}

Robbins, C. "The Regeneration Balance Sheet for Communities" (presentation at $\mathrm{HQE}^{2} \mathrm{R}$ work meeting No. 3 and working paper), Bristol, 2002.

Robinson, F., T. Blackman, and C. Stephens. "Monitoring and Evaluating City Challenge.” Research for Policy (1995): 135-45.

Russell, H., J. Dawson, P. Garside, and M. Parkinson. City Challenge: Interim National Evaluation. London: The Stationery Office, 1996.

Xing, Y., R. Horner, M. El-Haram, and J. Bebbington. "A Framework Model for Assessing Sustainability Impacts of Urban Development." Accounting Forum 33 (2009): 209-24.

Zuberi, D., and A. Taylor. "Urban Renewal in Vancouver, Canada," in The Routledge Companion to Urban Regeneration edited by M. E. Leary, and J. McCarthy, 292-302. London and New York: Routledge, 2013. 